\title{
Covid-19 (Koronavirüs) Salgınının Turist Rehberleri Üzerindeki Etkileri: Ankara Turist Rehberleri Odası Örneği
}

Ertuğrul DÜZGÜN*

Asena KURT**

\begin{abstract}
$\ddot{O} z$
Çin'in Wuhan kentinde ortaya çıkıp, tüm dünyayı etkisi altına alan yeni tip Koronavirüs salgınından turizm sektörü olumsuz etkilenmiştir. Sektörün en önemli aktörlerinden turist rehberleri de bu süreçte olumsuzluklar yaşamışlardır. Bu kapsamda çalışmanın amacı pandemi sürecinin rehberler üzerindeki etkilerini belirlemeye çalışmak olmuştur. Araştırmada Ankara Turist Rehberleri Odası'na bağlı, eylemli 16 turist rehberi ile çevrimiçi ve telefon aracılığıyla yarı yapılandırılmış görüşmeler gerçekleştirilmiştir. Görüşmelerden elde edilen veriler betimsel analiz tekniği ile çözümlenmiş ve ekonomik, güven ve gelecek planlamaları şeklinde gruplandırma yapılmıştır. Araştırmanın sonuçlarında, rehberlerin bu süreçte ekonomik anlamda ciddi sıkıntılar yaşadığı ve kendilerine sunulan maddi destekten çok düşük miktarlarda yararlanabildiği ortaya çıkmıştır. Güven konusunda ise rehberler, çalışma ortamında gerekli tüm önlemleri almalarına rağmen yine de kendilerini güvensiz hissettiklerini belirtmişlerdir. Gelecek planlamasında birçok turist rehberinin, mesleklerinin haricindeki alternatif seçeneklere, özellikle akademik kariyere yöneldikleri görülmüştür.
\end{abstract}

Anahtar Kelimeler: Koronavirüs (COVID-19), Pandemi, Turizm, Turist Rehberi.

\section{The Effects of Covid-19 (Coronavirus) Epidemic on Tourist Guides: The Case of Ankara Tourist Guides Chamber}

\begin{abstract}
The tourism sector has been adversely affected by the new type of coronavirus epidemic that emerged in Wuhan, China and affected the whole world. Tourist guides, one of the most important actors of the tourism sector, also experienced negativity during this period. The aim of the study is to try to determine the effects of the pandemic process on tourist guides. In this context, semi-structured interviews were held with 16 active tourist guides affiliated to the Ankara Chamber of Tourist Guides, online or via phone. The data obtained from the interviews were analyzed with the descriptive analysis technique and grouped as economic, trust and future planning. According to the results of the study, it was revealed that the tourist guides had serious economic difficulties during this period and were able to benefit from the financial support offered to them in very low amounts. As for trust, tourist guides stated that they still feel unsafe despite taking all necessary precautions in the working environment. In planning the future, it has been observed that many tourist guides have turned to alternative options, especially academic careers, apart from their professions.
\end{abstract}

Keywords: Coronavirus (COVID-19), Pandemic, Tourism, Tourist Guide.

Geliş/Received: 09. 09. 2020

Kabul/Accepted: 20. 10. 2020

* Bu çalışma için, yazarların 29243 sayılı başvuru dilekçesiyle Ondokuz Mayıs Üniversitesi Sosyal ve Beşerî Bilimler Etik Kurulu'ndan 23.09.2020 tarih ve 2020/575 sayılı karar ile etik kurul izni alınmıştır.

* Dr. Öğr. Üyesi, Bolu Abant İzzet Baysal Üniversitesi, Turizm Fakültesi, Turizm Rehberliği Bölümü, duzgunertugrul@gmail.com Orcid: 0000-0002-0786-3840

** Arş. Gör, Ondokuz Mayıs Üniversitesi, Turizm Fakültesi, Turizm Rehberliği Bölümü, asena.kurt@omu.edu.tr Orcid: 0000-0002-8337-6155

(Makale türü: Araştırma makalesi) 


\section{Giriş}

Çin'in Wuhan kentinde nedeni bilinmeyen bir zatürre vakası, ilk olarak 31 Aralık 2019'da Dünya Sağlık Örgütü'ne (DSÖ) bildirilmiştir. Ocak 2020'nin başlarında, yeni bir koronavirüs (COVID-19) enfeksiyonu doğrulanmış 41 hasta, Çin'deki hastanelere kabul edilmiştir (Huang vd., 2020). Virüs, ülkenin Wuhan bölgesinde hızla yayılmasına rağmen, başlangıçta dünyanın diğer bölgelerindeki siyasi liderler tarafından büyük ölçüde göz ardı edilmiş̧tir (Washington Post, 2020). Virüsü kontrol altına almak için Wuhan, bölgesel ve bireysel karantina önlemleri almıştır ve Çin'deki vaka sayıları şubat ayı ortasına kadar 80.000 civarında sabitlenmiştir. O zamana kadar, hava taşımacılığı, virüsü tüm kıtalara taşımış ve mart ayı ortasına kadar 146 ülkede yayılma göstermiştir. Dünya çapında teyit edilen enfeksiyonların sayısı hızla iki katına çıkmıştır. 15 Nisan'a kadar, 200'den fazla ülkede 2 milyona (125.000'den fazla ölümle) yaklaşan vakalar doğrulanmıştır (ECDC, 2020). Çoğu ülkede testler sınırlı olduğu için gerçek toplam vaka sayısı bilinmemektedir. Hastalığı önlemek için geçerliliği kanıtlanmış bir aşı bulunamadığından ve tedavi etmek için sınırlı tıbbi müdahaleler olduğundan dolayı çoğu ülke, karantina (ev izolasyonu, gönüllü/zorunlu karantina), sosyal izolasyon, okulların/üniversitelerin ve zorunlu olmayan işyerlerinin kapatılması, etkinliklerin iptal edilmesi veya ertelenmesi (örneğin, büyük konferanslar ve fuarlar, konserler ve festivaller, siyasi tartışmalar ve seçimler, spor mevsimleri ve yaz olimpiyatları) ve belirli sayılarda insanların toplanmasının yasaklanması gibi önlemler almıştır.

Uluslararası, bölgesel ve yerel seyahat kısıtlamaları; hava taşımacılı̆̆ı, turlar, ulaşım, konaklama, kafe ve restoranlar, kongreler, festivaller, toplantılar, spor etkinlikleri gibi çeşitli alanları etkilemiştir. Krizin bir sonucu olarak uluslararası hava taşımacılığı sektörü büyük bir darbe alırken; seyahat yasakları uygulayan, sınırları kapatan veya karantina dönemleri getiren birçok ülkede, uluslararası ve iç turizm hareketleri hızla azalmıştır. Ülkeler, dünyanın her yerinde bulunan yüz binlerce vatandaşını ülkelerine döndürmek için uğraş göstermişlerdir. Örneğin, 23 Mart'ta İngiliz Dışişleri Bakanı İngiliz turistleri evlerine dönmeye çağırmıştı; zorunlu uluslararası seyahat dışındaki herkese karşı tavsiyede bulunmuştur ve "uluslararası seyahatin, sınırların kapatılmasıyla daha da zorlaştı̆̆ını" vurgulamıştır (FCO- The Foreign \& Commonwealth Office, 2020).

Turizm sektörü, yapısı itibariyle çevresel, sosyal, dini ve/veya siyasi olaylardan etkilenmesinden dolayı bu süreçte sektörde kayıplar ve hasarlar yaşanmıştır. Salgın, işletmelere uğrattığı zararların yanı sıra, seyahat işletmeleri, konaklama işletmeleri çalışanlarında olduğu gibi, sektörün önemli grubunu oluşturan turist rehberlerinin işsiz kalmasına neden olmuştur. Sezonluk yoğunluğun fazla olduğu meslekte, turist rehberleri yaz sezonu boyunca oldukça yüksek tempoda çalışmaktadır. Sınırların birçok ülke ile hala kapalı olması ve bundan dolayı yurtdışından 
gelen turist sayısının az olması, yurtiçinde ise insanların çoğunluğunun bu süreçten dolayı yaşadığı kaygı ve endişe sebebiyle seyahatlerini ertelemesi, turist rehberlerinin ya daha az çalışmasına ya da hiç çalışamamasına neden olmuştur. Bu kapsamda, çalışmada pandemi sürecinden turist rehberlerinin ne derece etkilendiği ve bu etkilerin ne şekilde görüldüğü belirlenmeye çalışılmıştır. Araştırmanın ilk bölümünde salgının turizm sektörüne olan etkileri ile ilgili literatür incelenmiş, ardından araştırmanın ikinci bölümünde yöntem hakkında bilgi verilmiştir. Araştırmanın üçüncü bölümünde yapılan mülakatlardan elde edilen bulgular değerlendirilip tartış1ırken, son bölümde ise araştırmanın sonucu açıklanmıştır.

\section{Literatür}

\section{Dünyada Salgınların Turizme Etkileri}

Küresel turizm, geçmişte çeşitli krizlere maruz kalmıştır. 2000 ve 2015 yılları arasında meydana gelen büyük yıkıcı olaylar arasında 11 Eylül terör saldırıları (2001), şiddetli akut solunum sendromu (SARS) salgını (2003), 2008/2009'da ortaya çıkan küresel ekonomik kriz, domuz gribi (2009), 2015 Orta Doğu Solunum Sendromu (MERS) salgını bulunmaktadır (Gössling vd., 2020). Bunların hiçbiri turizmin küresel gelişiminde uzun vadeli bir düşüşe yol açmamıştır, sadece SARS (\%-0.4) ve küresel ekonomik kriz (\%-4.0) uluslararası varışlarda düşüşe yol açmıştır (World Bank 2020a, 2020b). Bu, turizmin yaşanan felaketlere rağmen dirençli olabildiğini göstermektedir.

2003 yılında SARS salgını, Çin ve Hong Kong'daki, Tayvan ve Kanada'daki vakalar ile birlikte DSÖ tarafından pandemi olarak tanımlanmıştır. SARS, turizm açısından incelendiğinde, Siu ve Wong (2004), Hong Kong için genel ekonomik etkinin beklendiği kadar şiddetli olmadığını, ancak ziyaretteki kısa vadeli düşüşün bir sonucu olarak turizmin önemli ölçüde etkilendiğini bildirmiştir. Hong Kong'a 2003 yılının Nisan ayında kara, deniz ve havayolu ile seyahat eden yolcu sayısının, Mart 2003 rakamlarına kıyasla düşüş gösterdiğini: havayolu yolcularının sayısı yüzde 77 , karadan seyahat edenlerin sayısı yüzde 52 ve deniz yoluyla gelenlerin sayısı ise yüzde 72 oranında azaldığını ifade etmişlerdir.

2009 yılında domuz gribi pandemi olarak tanımlanmıştır, ancak nispeten daha hafif yaşanmıştır (Gössling vd., 2020). Bununla birlikte, 2009 domuz gribi salgını dünya çapında yaklaşık 284.000 ölümle sonuçlanmıştır (Viboud ve Simonsen, 2012). Russy ve Smith (2013), pandeminin Meksika'daki turizm üzerindeki etkilerini incelemiştir ve beş aylık bir süre boyunca neredeyse bir milyon denizaşırı ziyaretçinin kaybedilmesinin, Avrupa pazarında yaklaşık 2,8 milyar dolarlık zarara dönüştügünü öne sürmüştür.

Dünyada, son 40 yılda bir dizi büyük salgın/pandemi yaşanmıştır. COVID-19 ise küresel ölçekte dünyanın neredeyse her ülkesinde görülmesi, işletmelerin kapatılması, seyahatlerin kısıtlanması ve etkinliklerin ertelenmesi gibi nedenler ile önceki krizlerden çok daha fazla 
Ertuğrul DÜZGÜN, Asena KURT

Covid-19 (Koronavirüs) Salgınının Turist Rehberleri Üzerindeki Etkileri: Ankara Turist Rehberleri Odası Örneği

büyüklüğe sahip olduğu söylenebilir. COVID-19 vakalarının sayısı küresel olarak artış gösterip yayıldıkça, seyahat kısıtlamaları Wuhan bölgesi merkez üssünden mart sonuna kadar çoğu ülkeye yayılmıştır. Ülke nüfusu verileri kullanarak, dünya nüfusunun \%90'ından fazlasının uluslararası seyahat kısıtlaması olan ülkelerde olduğu ve bu ülkelerin çoğunun sınırlı hava yolculuğu ve evde kalma dahil olmak üzere iç turizm konusunda bir ölçüde kısıtlamaya sahip olduğu tahmin edilmekteydi (Gössling vd., 2020).

Birleşmiş Milletler Dünya Turizm Örgütü (UNWTO) COVID-19'un sektör üzerindeki etkilerini, mart ayı başında ve sonunda yaptığı açıklamalar ile önemli ölçüde revize etmiştir. UNWTO (2020a) 6 Mart 2020 tarihli basın açıklamasında, pandeminin uluslararası turist varışlarının tahmin edilen \%3-4'lük büyüme yerine \%1-3 (2019'a kıyasla) azalmasına neden olacağını tahmin ederken; üç hafta sonra, 26 Mart'ta gerçekleştirdikleri bir basın açıklaması ile, bu değerlendirmeyi uluslararası varışlarda \%20-30 kayıp olarak güncellemiştir (UNWTO 2020b).

Pandemi sürecinde işten çıkarmalar ve iflaslarla ilgili raporlar devamında süre gelmiştir, İngiliz havayolu şirketi FlyBe piyasa baskısına yenik düşmüş ve 5 Mart 2020'te iflasını ilan etmiştir (Business Insider, 2020). Turizm sektörünün birçok alt dalı, hükümetin teşvik paketlerinden yardım talebinde bulunmuştur. İskandinav Havayolları (17 Mart 2020), Singapur Havayolları (27 Mart 2020) ve Virgin (30 Mart 2020) gibi büyük havayollarının yanı sıra Alman TUI (27 Mart 2020) dahil olmak üzere tur operatörleri milyar dolarlarca devlet yardımı talep etmişlerdir. Avustralya'daki Qantas Havayolları, geçmiş yııllarda rekor seviyede karlar elde etmesine rağmen, bu süreçte hükümet yardımı ararken personeline sert kesintiler yapması oldukça eleştirilen örneklerdendir (Butler, 2020). Birçok havayolu, yolcular arasındaki oturma mesafesi kuralları nedeniyle kapasiteyi azaltmış, bu nedenle yolcu sayısı keskin bir şekilde düşmüştür. IATA (2020), COVID-19 krizinin küresel havayolu yolcu gelirlerinin 2020'de 314 milyar ABD doları veya 2019 yılına kıyasla yaklaşık \%55 düşmesine neden olacağını tahmin etmiştir. Aynı zamanda, Asya-Pasifik havayolları, 2020'de 113 milyar ABD Doları veya 2019 yılına kıyasla \%50'lik bir gelir düşüşü yaşamıştır. COVID-19 salgınının bir sonucu olarak IATA, Şubat 2020'de kilometrelerce kargo tonu olarak ölçülen havacılık taşımacılığı talebinin 2019'daki aynı döneme göre \%1,4 azaldığını tahmin etmiştir. Seyahat kısıtlamaları konaklama sektörüne de zarar vermiştir. STR (2020), dünyanın tüm bölgelerindeki otel endüstrisinin, mevcut oda başına küresel gelirde çift haneli bir düşüş yaşadığını, Asya'nın (-\%67,8) ve Avrupa'nın (-\%61,7) en büyük düşüşleri kaydettiğini tahmin etmektedir. AHLA'nın (2020) çeşitli kaynaklardan yaptığ derlemelerde, COVID-19 salgınının, ABD’de gerçekleştirilen 9/11 Eylül terör saldırılarından turizm ekonomisi açısından 9 kat daha kötü etkiye sahip olduğunu göstermektedir; 2020 yılında gelir yaklaşık \%50 azalmıştır ve toplam 270 milyar \$ 'dan 124 milyar \$ kayıp; 10 otel odasından 8'i boştur (STR, 2020); 2020'nin otel doluluk oranı için en kötü yıl olacağı öngörülmektedir; 2020 
doluluk oranlarının 1933'teki Büyük Buhran döneminden daha kötü olduğu tahmin edilmektedir; otel çalışanlarının \%70'i işten çıkarılmıştır; kriz nedeniyle yaklaşık 1,6 milyon otel çalışanı işsizdir ve haftalık ücrette 2,4 milyar dolar kaybedilmiştir; kriz başladığından beri yaklaşık 3,9 milyon otel destekli iş kaybedilmiştir (Haryanto, 2020).

\section{Salgınların Sosyal ve Psikolojik Etkileri}

Doğal afetler gibi toplumu etkileyen krizler ile ilgili incelenen çalışmalar, yıkıcı olayların insanların zihinsel sağlıklarını kötü etkilediğini göstermektedir. Yaşanan yıkıcı olaylar sonucunda travma sonrası stres bozuklukları, depresyon, anksiyete ve diğer davranışsal ve psikolojik hastalıklar en çok karşı1laş1lan örneklerdendir (Makwana, 2019). Bu nedenle mevcut pandemi, psikolojik ve psikiyatrik hastalıklar için büyük bir risk oluşturmaktadır.

DSÖ, "sosyal mesafe" terimini, insanların kendilerini daha az yalnız ve yalıtılmış hissetmeleri için "fiziksel mesafe" olarak değiştirmiştir (Sood, 2020). Gerçekleştirilen bir metaanaliz çalışmasında, yalnızlığın tüm ölümlere neden olabilecek bir risk faktörü olduğu sonucuna varılmıştır (Rico-Uribe, 2018). Eğitim veya iş için ailelerinden uzakta yaşayan ya da sevdiklerinden ayrı yerlerde olan insanlarda, depresyon, anksiyete vb. zihinsel sağlık problemlerinin olma riski daha yüksektir. Bu duruma yalnız yaşayan yaşlı insanlar daha büyük ölçüde yatkındır (Sood, 2020).

Salgının bulaşıcılığını kontrol altına almada, salgının yayılması hususunda olumlu sonuçlar alınsa da psikolojik olarak olumsuz etkiler de bulunabilmektedir. Bireylerin birkaç günden birkaç haftaya kadar olan süreler için karantinaya alındığı çalışmaların incelenmesi, olası sonuçlara 1şık tutmaktadır (Brooks vd., 2020). Karantina sırasında sosyal temas eksikliği, özgürlük kaybı ve can sıkıntısından kaynaklanan sıkıntı ve sinirlilik yaşanırken, bazı çalışmalar depresif belirtiler de dahil olmak üzere uzun vadeli etkileri olduğunu göstermektedir (Liu vd., 2012). Daha uzun dönemler, daha zayıf zihinsel sağlık sonuçları (Hawryluck vd., 2004) ve artan öfke ile ilişkilidir (Jeong vd., 2016). İzolasyon dönemini uzatmak, insanları demoralize edebilir ve uyumsuzluğu artırabilir (Rona vd., 2007). İzolasyon sırasında yalnızlığın zihinsel sağlık etkileri, çoklu olumsuz zihinsel sağlık sonuçlarıyla bağlantılı olan rutin kaybıyla daha da kötüleşebilmektedir (Lyall vd., 2018).

Pandemi sonrası seyahat davranışlarında değişiklikler yaşanması muhtemel bir sonuçtur. Seyahat davranışları, kişisel ekonomik refah ve harcanabilir gelir, maliyet değişiklikleri, algılanan sağlık riskleri ve pandemik kısıtlamaların bir sonucu olarak değişen tüketim kapasitelerini içeren bir dizi faktörden etkilenmektedir (Lee ve Chen, 2011). Seyahat davranışlarının değişiklikleri üzerine yapılan çalışmalarda, insanların pandeminin kontrol altına alındıktan sonra bile hemen tatile çıkma niyetinde olmadıkları ve tatil yapacaklar ise kısa süreli planladıkları görülmüştür (Alaeddinoğlu ve Rol, 2020). 
Pandeminin insanlar üzerinde yarattığı kaygı ve endişe durumundan dolayı Nazneen vd. (2020) tarafından yapılan bir çalışmada, hijyen ve güvenlikten dolayı turistlerin seyahat planlamasında değişikliğe gittiklerini ve gelecek bir yıllık süre ile tatil planlarında azalmaya gittiklerini ortaya koymuşlardır. Tatile çıktıklarında ise turistler, aşırı kalabalık ve kitle turizmi destinasyonlarından kaçınma, daha az kalabalık yerlere bireysel seyahat etme eğiliminde bulunabilmektedir (Wang ve Ackerman, 2019). Bu durumun, bireylerin bilinmeyen şeylerden kaçınmaya motive ettiği ve turizmde yabancı düşmanlığ 1 gösterebileceği (yurtdışına daha az seyahat, yabancı yiyeceklerden kaçınma vb.) düşünülmektedir (Kock vd., 2019b). Zhang vd. (2005), 2003 SARS salgınını takiben Çinli turistlerin, bir tur grubu ile seyahat ederken ayrı yemek yemeyi tercih ettiklerini belirtmişlerdir. Halk sağlığını etkileyen krizler, turistlerin yemek yeme davranışını doğrudan değiştirebilmektedir.

Araştırmalar, ziyaretçilerin algılamış oldukları riskin destinasyon algısını olumsuz yönde etkilediğini göstermektedir (Khan vd., 2017; Loureiro ve Jesus, 2019). Bu riskler, sağlıkla ilgili sorunlar dahil olmak üzere çoğunlukla güvenlikle ilgili olmaktadır. Bu nedenle, COVID-19 salgını sonrasında turistlerin altyapısı ve yüksek kaliteli tıbbi tesisleri olan destinasyonları aramaları daha olasıdır (Wen vd., 2020). Güven konusundaysa, bir hastalık tehdidine maruz kalındığında turistlerin, yurt dışı yerine yurt içi seçimler yaparak kendi ekonomilerini desteklemeyi amaçladıkları görülmektedir (Gössling vd. 2020).

\section{Yöntem}

Çalışmada, pandemi sürecinden turist rehberlerinin ne derece etkilendiğinin ve sosyal, psikolojik ve ekonomik olarak ne tür etkilerinin olduğunun belirlenmesi amaçlanmıştır. $\mathrm{Bu}$ bağlamda, veri toplama sürecinde nitel araştırma yöntemlerinden yarı yapılandırılmış görüşme kullanılmıştır. Yarı yapılandırılmış görüşmeler, yapılandırılmış görüşmeler kadar katı olmayıp, yapılandırılmamış görüşmeler kadar da esnek değildir; ikisinin arasında yer almaktadır (Karasar, 1995:165). Belirli bir amaç doğrultusunda iki veya daha fazla kişi tarafından yapılan tartışmalarda niçin, nasıl gibi sorulara cevap ve belirli konularda derinlemesine bilgi edinilmesi sağlamasından dolayı en çok tercih edilen yöntemler arasında bulunmaktadır (Yıldırım ve Şimşek, 2011). Bu kapsamda hazırlanan görüşme sorularının belirlenmesinde ilgili literatürden yararlanılmıştır (Demir, Günaydın ve Demir, 2020; İbiş, 2020; Mert ve Alan, 2020; Zengin, Topçuoğlu ve Kayğın, 2020).

Çalışmada veri elde edilecek turist rehberlerinin tespit edilmesinde kartopu örneklem yöntemi kullanılmıştır. Kartopu, evrenin büyüklüğü veya bilgide eksik olduğu zamanlarda ya da evrenin oluşturduğu birimlere ulaşımın zor olduğu zamanlarda kullanılan bir yöntemdir (Patton, 2005). Bu kapsamda Ankara Turist Rehberleri Odası'na bağl1 16 turist rehberi ile online görüşme gerçekleştirilmiştir. Alınan cevaplar tekrarlamaya başladığı vakitte, doygunluğa ulaştığı 
düşünüldüğünden mülakatlar kesilmiştir. Nitel çalışmalarda örneklem sayısı belirlenmesine dair bir kural bulunmamasından dolayı, veriler doygunluğa ulaşılınca araştırmalar sonlandırılmaktadır (Patton, 2002). Araştırma grubunu oluşturan katılımcılar seçilirken "Ankara Turist Rehberleri Odası"na kayıtlı olmalarına ve eylemli turist rehberi olmalarına dikkat edilmiştir.

Görüşmeler pandemi sürecinden dolayı online veya telefon aracılığıyla gerçekleşmiştir. Verilere 4 Ağustos 2020 ile 21 Ağustos 2020 tarihleri arasında ulaşılmıştır. Yarı yapılandırılmış görüşme formları şeklinde gerçekleştirilen görüşmeler ortalama 30'ar dakika sürmüştür. Verilerin çözümlenmesinde ise betimsel analiz tekniği uygulanmıştır.

Covid-19'un en çok etkilemiş olduğu alanlardan olan turizm sektöründe hizmet veren ve çalışma olanağı doğrudan yurtdışından gelen insanlarla ilgili olan turist rehberlerine virüsün etkilerini belirlemeye yönelik aşağıdaki sorulara cevap aranmıştır;

1. Covid-19 sürecinde ekonomik anlamda nasıl ve ne kadar kayıp yaşadınız?

2. Covid-19 sürecinde herhangi bir ekonomik destekten faydalandınız mı?

3. Covid-19'dan dolay1, turizm sektöründe meydana gelmiş olan ve gelmesi muhtemel ekonomik kayıplar için, çözüm önerileriniz nelerdir?

4. Çalıştığınız dönemde Covid-19'a karşı kendinizi güvende hissediyor musunuz?

5. Turlarınızda konuklarınızın güvenliği için nasıl önlemler aldınız?

6. Covid-19 sonrası turistlerin konaklama, seyahat, restoran işletmelerinden beklentileri neler olacaktır?

7. Covid-19 sonrasında, turizmde normalleşme ne zaman gerçekleşir?

8. Covid-19 salgını sonrasında başka bir meslek yapmayı düşünüyor musunuz?

\section{Bulgular ve Tartışma}

Araştırma, üye sayısının yoğunlukta olduğu Ankara Turist Rehberleri Odası'na (ANRO) bağl1 16 eylemli turist rehberi ile gerçekleştirilmiştir. Katılımcıların her biri için K1, K2, K3...K16 şeklinde birer kod verilmiş, demografik ve mesleki özellikleri ortaya çıkarılmıştır, daha sonra ise yaşanan sürecin turist rehberleri üzerindeki etkilerine ilişkin görüşlerine yer verilmiştir. $\mathrm{Bu}$ doğrultuda belirlenen katılımcılara ilişkin veriler Tablo 1'de verilmiştir. 
Ertuğrul DÜZGÜN, Asena KURT

Covid-19 (Koronavirüs) Salgınının Turist Rehberleri Üzerindeki Etkileri: Ankara Turist Rehberleri Odası Örneği

Tablo 1: Araştırmaya Katılan Turist Rehberlerine İlişskin Bilgiler

\begin{tabular}{|l|l|l|l|l|l|l|l|}
\hline Katılımcı & Cinsiyet & $\begin{array}{l}\text { Medeni } \\
\text { Durum }\end{array}$ & Eğitim & $\begin{array}{l}\text { Çalışma } \\
\text { Alanı }\end{array}$ & Şehir & $\begin{array}{l}\text { Yabancı } \\
\text { Dili }\end{array}$ & Tecrübe \\
\hline K1 & Erkek & Evli & Lisans & Ülkesel & Konya & İngilizce & 10 \\
\hline K2 & Erkek & Evli & Lisans & Ülkesel & Karabük & İngilizce & 15 \\
\hline K3 & Kadın & Evli & Lisans & Ülkesel & Ankara & İngilizce & 8 \\
\hline K4 & Erkek & Bekar & Lisans & Ülkesel & Ankara & Fransızca & 35 \\
\hline K5 & Kadın & Bekar & Lisans & Ülkesel & Ankara & İngilizce & 20 \\
\hline K6 & Erkek & Evli & Önlisans & Ülkesel & Ankara & İngilizce & 11 \\
\hline K7 & Erkek & Bekar & Önlisans & Ülkesel & Eskişehir & İngilizce & 9 \\
\hline K8 & Erkek & Bekar & Önlisans & Ülkesel & Ankara & İngilizce & 14 \\
\hline K9 & Erkek & Bekar & Lisans & Ülkesel & Ankara & İngilizce & 12 \\
\hline K10 & Kadın & Bekar & Lisans & Ülkesel & Ankara & İngilizce & 11 \\
\hline K11 & Erkek & Evli & Lisans & Ülkesel & Afyon & İngilizce & 10 \\
\hline K12 & Kadın & Evli & Lisans & Ülkesel & Kastamonu & İngilizce & 16 \\
\hline K13 & Kadın & Bekar & Lisans & Ülkesel & Ankara & İngilizce & 22 \\
\hline K14 & Erkek & Bekar & Lisans & Ülkesel & Ankara & İngilizce & 12 \\
\hline K15 & Kadın & Bekar & Lisans & Ülkesel & Ankara & İngilizce & 11 \\
\hline K16 & Erkek & Evli & Önlisans & Ülkesel & Bartın & İngilizce & 7 \\
\hline
\end{tabular}

Araştırmaya katılan katılımcıların büyük bir çoğunluğu erkek $(\% 62,5)$, bekar $(\% 56,2)$ ve eğitim durumu lisans $(\% 81,2)$ olan bireylerden oluşmaktadır. Tamamını ülkesel rehberlerin oluşturduğu örneklem grubunda, ANRO'nun yetkili olduğu iller (Afyonkarahisar, Ankara, Bartın, Çankırı, Çorum, Eskişehir, Karabük, Karaman, Kastamonu, Kırıkkale, Konya ve Zonguldak) göz önüne alındığında, araştırmaya katılan katılımcıların da çoğunluğu Ankara ilinde ikamet etmektedir. Rehber istatistiklerinde de yabancı dillere göre turist rehberi sayılarında İngilizce dilinde rehber sayısı diğer dillerden oldukça fazladır. Araştırmada da ortaya çıktığı üzere katılımcıların tamamına yakını İngilizce dilinde turist rehberidir. Mesleki deneyimlerine göre incelendiğinde ise büyük çoğunluğu en az 10 yıl tecrübeli turist rehberlerinden oluşmaktadır.

Araştırmada katılımcılarla yapılan görüşmeler ve kavramsal yapı itibariyle veri analizine çerçeve oluşturabilmek üzere sorular ekonomik, güven ve gelecek planlamaları olarak üç şekilde gruplanmıştır.

\section{Ekonomik}

Pandemi sürecinde insanların yaşamış oldukları en önemli sorunların başında kısıtlamalar yüzünden mesleklerini icra edememeleri gelmiştir. Ekonomik kazanç için önceki yılın sezon sonu olan Ekim ayından itibaren sezonun açılacağı Mart-Nisan aylarını bekleyen rehberler tüm dünyada ve ülkemizde hızla yayılan Koronavirüs sebebiyle büyük ekonomik sıkıntılar içerisine 
girmişlerdir. Bu kapsamda katılımcılara "Covid-19 sürecinde ekonomik anlamda nasıl ve ne kadar kayıp yaşadınız?” sorusu yöneltilmiş ve alınan çarpıcı cevaplar aşağıdaki gibi olmuştur;

"Severek yaptı̆̆ımız mesleğimiz bu sene pandemi yüzünden bizi ekonomik yönden çok kötü etkiledi. Geçen sene en son ekim ayında tura çıkmışıım. Geçen seneki kazandı̆̆ım ücret ancak 2019 yılını tamamlamaya yetti. Bu yılın başından beri hep sezon açıldığında ödemek üzere borçlanıyordum. Maalesef ki bu sene sadece mart ayında bir tur aldım ve o zamandan beri tura çıkmadım. Ekonomik olarak sorunlar yaşadığım için kiradaki evimi kapatarak yaklaşık 15 yıl önce ayrıldığım ailemin yanına tekrar dönmek zorunda kaldım”. (K10)

İlgili literatür incelendiğinde İbiş (2020), salgının, Türkiye'de faaliyet gösteren seyahat acentelerini nasıl etkilediğini ortaya çıkarmak amacıyla İstanbul'da faaliyet gösteren 11 seyahat acentesi yetkilileri ile görüşmeler gerçekleştirmiştir. Görüşmeler sonucunda acentelerin bu süreçte oldukça zorlandığı, sabit giderleri devam etmesine rağmen gelir kaynaklarının kesildiği, kısa vadede toparlanmalarının ise zor olacağı sonuçlarına ulaşmışlardır. Aynı şekilde Karim vd. (2020) Covid-19 salgınının Malezya'da konaklama sektörü üzerinde etkilerinin nasıl gerçekleştiğini belirlemeye çalışmıştır. Bu kapsamda yaşanan süreçte, otellerin ciddi anlamda gelir kaybı yaşayacaklarını belirtmişlerdir. Bahar ve İlal (2020) ise salgının turizm sektörü üzerindeki ekonomik etkilerini belirlemek amacıyla yaptıkları çalışmada, salgından dolayı oluşacak talep şoklarının, sektörde istihdam ve gelir kayıplarına yol açacağı sonucuna ulaşmışlardır.

Dünyada ve ülkemiz özelinde pandemi sürecinin çalışanlar üzerindeki ekonomik etkilerini hafifletebilmek üzere ülke yönetimleri tarafindan birtakım ödeme kolaylıkları, borç ertelemeleri ve ihtiyaç kredileri gibi kolaylıklar sunulmaktadır. Çok sayıda konaklama işletmesi, seyahat acentesi, yiyecek içecek işletmesi, eğlence ve hediyelik eşya işletmesi ve turist rehberine ekonomik kazanç sağlayan hizmet sektörünün önemli bir alt dalı olan turizmde, rehberlere yönelik de bir kredi sunulmuştur. Konuyla ilgili olarak katılımcılara sunulan "Covid-19 sürecinde herhangi bir ekonomik destekten faydalandınız mı?" sorusuna verilen yanıt aşağıdaki gibidir;

"Turizm denilince akla öncelikle otel gelir, sonra acenteler gelir daha sonralart ise restoranlar ve rehberler gelir. Bu yüzden ekonomik destekler önce otellere ve acentelere verilir, eğer kalırsa bütçe, küçük bir kısımda rehberlere pay edilir. Keza Covid sürecinde de bu şekilde olmuştur. Bakanlık ve Rehberler Birliği rehberlere yönelik 10 bin liraya kadar faiziyle 36 ayda geri ödemeli kredi sunmuştur. Bu kampanya bankaların diğer normal vatandaşlara verdiği kampanyanın aynısıdır. Tek avantajı rehberler bankaya gitmeden başvurusunu e-devlet üzerinden yaptılar. Biz de başvurduk ancak bahsedildiği gibi 10 bin değil daha düşük rakamları kredi olarak aldik." (K6) 
Konuyla ilgili Doğancılı (2020) çalışmasında, salgın sonrası Türkiye'de turizm sektöründe ortaya konulan destek uygulamalarını ortaya koymuştur. Bu kapsamda seyahat acenteleri, turist rehberleri ve ulaştırma sektörü için yeterli düzenlemelerin olmadığı sonucuna ulaşmıştır. Ayrıca bireyleri tatile yöneltmek için hükümetin sunduğu tatil kredisinin, artan tatil fiyatları ve yaşanılan iş kayıplarından dolayı ziyaretçiler için de yetersiz olduğunu ifade etmiştir. İbiş (2020) de seyahat acentelerine sunulan destek kredilerinin yetersiz olduğu ve acentelerin daha fazla desteğe ihtiyaç duyduğu sonucuna ulaşmıştır.

Turizm sektörü; kriz, salgın, doğal afet gibi olağanüstü durumlardan en çok etkilenen sektörlerin başında geldiği söylenebilir. Ülkeler ve destinasyonlar, oluşan bu olağanüstü durumlardan korunmak için belli tedbirler almak durumundadırlar. Çünkü bahsedilen olağanüstü durumların her an olma ihtimali olduğu düşünüldüğünde gelirlerinin büyük bir kısmını turizmden elde eden kişilerin alternatif bir planlarının olması önemli görülmektedir. Konuyla ilgili olarak seyahat acentesi sahibi ve aynı zamanda rehber olan bir katılımcıya sorulan "Covid-19' dan dolayı, turizm sektöründe meydana gelmiş olan ve gelmesi muhtemel ekonomik kayılar için, çözüm önerileriniz nelerdir?” sorusuna verilen cevap şu şekildedir;

"Sektörü iyi tanıyan ve dünyanın birçok ülkesi ile ortak işler yapan birisi olarak bu konuda söylenecek çok şey var. Bizim ülkemiz gibi gelişmekte olan ülkeler teknoloji ve sanayi alanında çok fazla üretim yapamadıkları için doğal zenginliklerini pazarlarlar. Ancak şunun farkına varamayız. Bu göller, yeşillikler, tarihi yerler... hepsinin bir ömrü var. Hepsi ileride tükenebilecek olan şeyler. Biz ekonomimizi sadece turizme dayandırıyoruz. Böyle olunca da en ufak bir siyasi çatışma veya doğal afet olduğunda ekonomimiz büyük darbe görüyor. O sene turizm bitiyor neredeyse. Covid salgını da bunlardan birisidir. Çözüm olarak bu süreçten bir ders çıkarıp geleceği yakalamak için teknoloji, ar-ge ve diğer alanlara yatırım yapmalıyız. Aksi taktirde bu ekonomik süreçten çıkmak mümkün olmayacak." (K8)

Ekonomik kayıplara yönelik çözüm önerileri için Bakar ve Rosbi (2020), Covid-19 salgınının turizme etkisi üzerinde yaptıkları çalışmada, turizme yönelik talepte düşüşler yaşanacağını, azalan talebin önlenmesi için de hükümetin önleme eylemlerinin bulunması gerektiğini ifade etmişlerdir. Khadka vd. (2020) ise Nepal turizmi için salgından daha fazla etkilenilmemesi adına turizm sektörü paydaşlarının stratejik bir plan hazırlamaları gerektiğini vurgulamışlardır. Ranasinghe vd. (2020) tarafından yapılan çalışmada esnek fiyat ve iptal politikalarında kolaylıkların, otelcilik sektöründe uzun vadede fayda sağlayacağını, aynı zamanda turistlerin zihninde olumlu imajı yeniden oluşturmak için yerel ve uluslararası anlamda pazarlama ve tanıtım kampanyalarının başlatılmasının önemli olduğunu belirtmişlerdir. Sheresheva (2020) ise Rus turizm endüstrisinde ekonomik toparlanma yaşanabilmesi için iç turizmin desteklenmesi gerektiğini ifade etmiştir. 


\section{Güven}

İnsanların çalışmış oldukları yerlerde kendilerini güvende hissetmeleri önemli bir husus olarak görülmektedir. Maslow'un İhtiyaçlar Hiyerarşisinde dahi yeme, içme ve barınma gibi fizyolojik ihtiyaçlardan hemen sonra güven hususu gelmektedir. Çalışma ortamlarında insanların bir araya gelmesiyle birlikte virüsün bulaşma riski de artmaktadır. Turist rehberleri ise otobüslerde, müze ve ören yerleri ile diğer turistik alanlarda genel itibariyle kalabalık gruplara hizmet verdikleri için bu risk grubunda bulunmaktadırlar. Bu sebeple herhangi bir salgın veya olağanüstü durumda rehberlerin ilk etkilenecek kişilerden oldukları düşünülebilir. Buradan hareketle bir katılımcıya sorulan 'Çalıştığınız dönemde Covid-19'a karşı kendinizi güvende hissediyor musunuz? sorusuna verilen yanıt aşağıdaki şekilde olmuştur;

"Rehberler herkesten önde giderler. Bir restorana girilecektir ilk rehber girer, bir otele girilecektir ilk rehber gider, bir sorun olmuştur ilk rehber müdahale eder. Yani rehber turdaki tüm riskleri alır. Bu sene sadece bir tane tura çıktım. Mart ayının yanılmıyorsam 3. haftasıydı. Virüs ülkemizde yok deniyordu. Ancak dünyanın her yerinde yayılmışken, ülkemize her yerden akın akın insan gelirken, havaalanları ăgzına kadar doluyken bizde olmaması bana mantıklı gelmiyordu. Acaba Covid testi bizim ülkemizde yapılabiliyor muydu? Tur boyunca aklıma bu sorular geldi durdu. Otobüs ağzına kadar insan doluydu. Hatta acente benim koltuğum olan 3-4 numaralı koltukları bile satmıştı. Otobüsün önünde yedek kaptan ve muavin ile iç içe gidiyorduk. Şimdiye olsam belli olurdu herhalde ancak çalıştı̆̆ım dönemde Covid 19'a karşı kendimi güvende hissetmedim." (K3)

Güven konusuna ilişkin Zengin, Doğan ve Kayğın (2020) aşçılara yönelik yaptığı çalışmada benzer bir sonuca ulaşmıştır. Araştırma sonucunda aşçıların, restoran sahiplerinin yeterli gelir elde edememelerinden dolayı işletmelerin kapatılması ve işsiz kalınması korkusu ile karşı karşıya oldukları, aynı zamanda güven konusunda da çalışanların bu süreçte kendilerini güvende hissetmedikleri görülmüştür.

Turlardaki tüm sorumluluğu üstlenen rehberler tura katılan misafirlerin sağlık güvenliği için de belli görevler üstlenmektedir. Araştırmaya katılan çoğu rehber Covid sürecinde kendi güvenliğini tehlikeye atmamak için tur almadıklarını belirtmişlerdir. Tur alanlar ise Kültür ve Turizm Bakanlığı tarafından yayımlanan "Turist Rehberliği Hizmetinde COVID-19 Pandemi sürecinde Uyulması Gereken Kurallara İlişkin Genelge"ye uygun davranmaya çalıştıklarını ifade etmişlerdir. Tur alan az sayıdaki rehbere iletilen "Turlarınızda konuklarınızın güvenliği için nasıl önlemler aldınız?" sorusuna karşılık olarak verilen yanıt aşağıdaki şekildedir;

"Covid'in gençleri çok etkilemediği, çoğunlukla yaşlıları etkilediğine yönelik yapılan açıklamalardan sonra yaşadığım bölgeye gelen turlarda rehberlik yapıyorum. Şehir dışına gitmemeye özen gösteriyor, bulunduğum bölgenin günübirlik turlarını allyorum. Anlatımlarımı 
Ertuğrul DÜZGÜN, Asena KURT

Covid-19 (Koronavirüs) Salgınının Turist Rehberleri Üzerindeki Etkileri: Ankara Turist Rehberleri Odası Örneği

mümkün olduğunca otobüsün en ön kısmindan yaplyor, çift maske takıyor, sık sık dezenfektan slkıyorum. En büyük hengâme, tur aracına iniş ve binişlerde oluyor. Konukların sosyal mesafe kuralına uyarak inip binmelerini defalarca rica etmeme rağmen halen kapı önlerinde ylğılmalar oluyor. Yurtdlşı uçuşları henüz açılmadĭ̆ için az sayıdaki yerli gruplara hizmet vermek durumunda kallyoruz. Yerli gruplara söz dinletmek yabancı gruplara göre çok daha zor. Bu yüzden biz ne kadar önlem alsak da içlerinde 'bana bir şey olmaz' edasinda gezen onca insan denk geliyor." (K16)

Mevcut literatür incelendiğinde, Chang vd.'nin (2020) salgın sonrası sürdürülebilir turizm ile ilgili yaptıkları çalışmada turistlerin yola çıkıştan varış noktasına kadarki destinasyonlarda sosyal mesafenin korunması gerektiği, kişisel koruma ekipmanlarının kullanılmasının çok önemli olduğu, otel giriş çıkışları, yemek servisi ve sosyal faaliyetler gibi yoğunluğun olduğu zamanlarda sosyal mesafenin korunmasının daha da önem arz ettiğine dikkat çekmiştir.

\section{Gelecek Planlamaları}

Gelecekle ilgili yapılan planlamalarda insanların tercihlerinde farklılıkların olacağına yönelik neredeyse tüm katılımcılar ortak görüş belirtmişlerdir. Konuya genel olarak bakıldığında insanlar zaman, emek ve maliyet sebebiyle kültür turlarına katılmaktadır. Çünkü münferit olarak yapacakları seyahatlerde; gidilecek yeri araştırmak için zaman harcayacak, araç kullanma, bilgi edinme ve araştırma gibi faaliyetleri yerine getirebilmek için emek verecek, münferit seyahatler yaptıkları için çok fazla yakıt ve konaklama ücreti ödemek durumunda kalacaklardır. Paket turlarda ise insanların zaman, emek ve paralarının büyük kısmı kendilerine kalmaktadır. Ancak yaşanan koronavirüs salgını sebebiyle insanlar kalabalık turlardan ziyade bireysel olarak seyahatler yapmaya ve çok fazla gidilmeyen bakir alanları tercih etmeye başlamışlardır. Konuyla ilgili olarak "Covid-19 sonrası turistlerin konaklama, seyahat, restoran işletmelerinden beklentileri neler olacaktır?” sorusuna verilen en çarpıcı cevap aşağıdaki şekildedir;

“İnsanları şu şartlar altında tura çekmeniz çok zor. Her ne kadar maske de taksanız, kolonya da dă̆ıtsanız, ateş de ölçseniz korkuları devam edecek. Rahat edemedikleri için de turlara gelmeyecekler. Kimse kimseye güvenmiyor, herkes birbirine korona olmuş gibi bakıyor. Uzun vadede insanların beklentileri şu olacak: Bir kere kapalı alanlarda yaplan turistik faaliyetlere katılmak istemeyecekler. Özellikle açık havada yapılan turizm faaliyetlerine yönelecekler. Örneğin çok lüks 5 yıldızlı oteller yerine bağımsız odaları olan Bungalow ve Serender gibi evlerde kalmak isteyecekler. Seyahatlerini kendi araçlarlyla yapmak isteyecekler. Yemek için seçtikleri restoranlar açık havada ve doğayla iç içe olan yerler olacak. Bu sebeple yatırımcılar buna göre yatırımların yapmaları faydalarına olur." (K11) 
Salgın sonrasındaki turist davranışları ve turistlerin beklentileri ile ilgili benzer çalışmalara bakıldığında, Aydın ve Doğan (2020), salgın sonrası turizm sektöründe meydana gelecek değişimler içerisinde turistlerin davranışlarını incelemiş ve turistlerin kitle turizminden ziyade kamp, karavan, sezonluk konut kiralama, yat kiralama gibi ürünlere yöneleceğini belirtmişlerdir. Demir vd. (2020) ise turistlerin tercihlerinin değişeceği düşünceleriyle birlikte, teknoloji temelli hizmetlerin bu süreçten sonra artacağı, butik otellerin tercih edileceği, münferit seyahatlerin gerçekleşeceğini tahmin etmişlerdir. Kıvılcım (2020), salgından sonra turizm sektöründe değişiklikler olacağını, temassız dijital işlemler, izole tatiller ve sosyal mesafeli turların ön planda olacağını belirtmiştir. Yenişehirlioğlu ve Salha (2020) ise salgının Türkiye iç turizmine etkilerini belirleyebilmek adına yaptıkları çalışmada turistlerin de kendilerini henüz güvende hissetmeyip, 2020 yılının yaz aylarında tatile gitmek istemediklerini, tatile çıksalar bile insan sayısının az ve sosyal mesafenin fazla olduğu yazlık, bungalow, yayla gibi yerlere yöneleceklerini belirtmişlerdir.

Ne zaman biteceği belli olmayan Covid-19 sürecinde katılımcılar normalleşmenin oluşması için aşının bulunmasının şart olduğu yönünde birleşmişlerdir. İnsanların birbirlerine karşı olan güvenlerini geri kazanmaları, rahatça dışarı çıkabilmeleri ve kısacası günlük yaşantılarına göre dönmeleri sağlanmadan turizmde normalleşmenin olması beklenmemektedir. Normalleşme süresi için ise 2020 y1lı zaten gözden çıkarılmış olup, 2021 yılı kaybedilmemeye çalışılmaktadır. Bu açıklamaları destekler nitelikte bir katılımcının "Covid-19 sonrasında, turizmde normalleşme ne zaman gerçekleşir?” sorusuna vermiş olduğu yanıt aşağıdaki gibidir;

"Dünyada geçmişte de bu tip salgınlar vardl. Ancak diğerlerinde bu kadar çaresiz kalındı̆̆ını hatırlamıyorum. Her gün bir dolu doktor farklı kanallara çıkarak virüsün biteceği veya bitmeyeceğiyle ilgili açıklamalar yapıyor. Tüm haber kanallarının yarısı Koronavirüs ile geçiyor. $\mathrm{Bu}$ şekilde devam ederken nasıl normalleşme olacak? Normalleşme olması için insanların yaşanan olumsuz durumu unutmaları gerek. Yani odaklarını farkl bir şeye kaydırmak gerek. Hal böyle olduktan sonra aşı bulunsa da bu korku bir süre daha devam edecektir. Bu yılı zaten kaybettik ve birçok acente ve rehber bu yüzden iflas etti veya iflasin eşiğine geldi. Ĕger gelecek sene de virüs bu hızla devam ederse üzülerek söylüyorum ki ülkemiz turizmi bir yll daha koronavirüsü kaldırmaz." (K5)

Bu konuda benzer şekilde Demir vd. (2020) de çalışmalarında turizmde normalleşmenin gelecek sene, yani 2021 yılında gerçekleşebileceği sonucuna ulaşmışlardır. 2020 yılı için dış pazar hareketlerine umut bağlanmaması gerektiğini, hatta başa baş tamamlanmasının bile yeterli olacağını ve 2021 yılı için ise tahmin ve beklentilerin yüksek olacağını ifade etmişlerdir. Kiper vd. (2020) de turizm akademisyenlerinin görüşlerine yer verdiği çalışmalarında turizmde normalleşmenin 1-2 yıl süreceği sonucuna ulaşmışlardır. 
Büyük çoğunluğu bir seyahat acentesine bağlı olmayıp bağımsız olarak çalışan rehberler korona sürecinden en fazla etkilenen kesimde yer almaktadırlar. Katılımcılara sorulan "Covid-19 sonrasında başka bir meslek yapmayı düşünüyor musunuz?” sorusuna \%60’i “Evet” cevabını vermişlerdir. Hayatlarını idame ettirebilmek için tura çıkıp para kazanmak zorunda olan rehberler, yurtdışı uçuşlarının kısıtlanması ve sokağa çıkış yasakları ile birlikte çalışamamış, önceki sezondan kazandıklarını da tükettiklerinden maddi olarak zor duruma düşmüşlerdir. $\mathrm{Bu}$ süreç rehberleri sadece maddi yönden zorlamamış, sosyal ve psikolojik yönden de etkilemiştir. Kalabalık ortamlarda ve özgür yaşam tarzını benimsemiş olan rehberler yapıları gereği pandemi sürecinden oldukça olumsuz etkilenmişlerdir. Konuyla ilgili olarak katılımcılar tarafından verilen cevaplar aşă̆ıdaki gibidir;

"Turist rehberliği küçüklükten beri hayalim olan bir meslekti. Her ne kadar her turda sıkıntılar yaşasak da her daim severek yaptığım bir iş̧tir. Ama maalesef bizim işimiz pimi çekilmiş bir bomba gibi. Siyasi bir çatışma olur, turist gelmez biz iş yapamayız, doğal afet olur turist gelmez iş yapamayız, terör saldırısı olur bölgeye gidemeyiz iş yapamayız... Turist rehberliği belki de meslekler arasında en fazla riski olan mesleklerdendir. Şu an evli olmadı̆̆ım için buna dayanabiliyorum ama ileride ne kadar daha dayanacağımı bilmiyorum. Ankara'da yaşarken mecburen Kayseri'ye döndüm. Babama işlerinde yardım ediyorum. Bu şekilde devam ederse zaten rehberlik mesleğini ileride yapan kişi sayısının oldukça azalacă̆ını düşünüyorum.” (K7).

"Pandemi sürecinde ben de diğer birçok rehber arkadaşım gibi ALES'e hazırlanıyorum. Yabancı dilimizin olması sebebiyle belki yüksek lisans yaparsak sizin gibi akademisyen olabiliriz. En azından her ay belirli bir gelirimiz olur da kendimizi garantiye alırı.” (K9)

"Çocuğunun turist rehberi olmasını isteyen aile azdır diye düşünüyorum. Covid sürecinden dolayı biz de ailemizle sorunlar yaşamaya başladık. Kamu Personeli Seçme Sınavı'na çalışarak memur olmam yönünde baskılar görüyorum. Sanırım bu şekilde devam ederse yaşım iyice geçmeden önümüzdeki birkaç yılı sınavlara hazırlanan bir öğrenci modunda geçireceğim.", (K15)

Mesleğin geleceği ile ilgili Kiper vd. (2020) salgın ile oluşan krizlerin turizm faaliyetleri üzerindeki etkilerini, turizm akademisyenleri tarafından değerlendirmiştir. Bu kapsamda turizm akademisyenlerinin büyük bir çoğunluğunun bu durumdan endişe duyduğu, salgının meydana getireceği ekonomik, politik ve sosyal gelişmelerin mesleklerinde bir tehdit unsuru oluşturacağ sonuçlarına ulaşmışlardır.

\section{Sonuç}

Doğal afetler ve salgınlar gibi beklenmedik olayların yaşamın tüm alanları üzerinde kapsamlı etkileri vardır. Bütün dünyanın seferber olup, mücadele ettiği COVID-19 salgınından en çok etkilenen ve oldukça zarara uğrayan sektörlerden biri olan turizm sektöründe, turizm 
paydaşları üzerinde çok sayıda sosyo-kültürel ve psikolojik sorunlar, ekonomik kayıplar yaşanmıştır. Öncelikle psikolojik olarak başlayan kaygı ve endişeler, devamında yaşanan mali sorunlar ve işten çıkarılmalar ile daha da artış göstermiştir. Pandemi nedeniyle hem yerli hem de yabancı turistlerin rezervasyonlarını iptal etmesi, bununla birlikte yaşanan seyahat kısıtlamaları, sınırların kapatılması, tüm hava seyahatlerinin iptal edilmesi turizm sektöründe çalışanların, işlerini kaybetmelerine neden olmuştur.

Salgınla birlikte tüm turizm faaliyetlerinin de durma noktasına gelmesi ile sektörün bel kemiğini oluşturan kollarından biri olan turist rehberleri de bu süreçte oldukça zorlanmıştır. Çalışmada, turist rehberlerinin pandemi sürecinde psiko-sosyal ve ekonomik olarak ne düzeyde etkilendiği belirlenmeye çalışılmıştır. Görüşmelerden elde edilen veriler doğrultusunda sonuçlar 3 kategoride ele alınmıştır. Ekonomik olarak; geçimini tamamen bu meslekten sağlayan ve yüksek sezona bel bağlayan turist rehberleri için bir turizm sezonu boyunca işsiz kalmak, ciddi seviyelerde ekonomik kayıpları da beraberinde getirmiştir. Ekonomik etkileri bir nebze de olsun hafifletebilmek adına Kültür ve Turizm Bakanlığı ile Turist Rehberleri Birliğince turizm sektörünün diğer dallarında olduğu gibi turist rehberlerine de kredi imkânı sunulmuştur. Ancak araştırmadaki bulgulara göre sunulan bu imkânın, halka ve rehberlere sunulan imkân arasında herhangi bir fark olmadığı görülmüştür. Rehberler üst limitten değil de daha düşük miktarlarda kredi imkanından yararlanabilmişlerdir.

Yapılan gruplandırmada ikinci kategori olan güven konusunda; turist rehberleri, kalabalık gruplar ile karşı karşıya kalmaktadır ve bundan dolayı salgından en çok etkilenecek kişilerden olabileceği düşünülmektedir. Turizm sektörünün vitrinini oluşturmasından dolayı turist rehberleri, turdaki tüm riskleri de üzerine almaktadır. Salgının başlangıç sürecinden şu ana kadar, olayın ciddiyetinin farkında olmayan acente yetkilileri ve tur katılımcılarından dolayı rehberler güvensizlik yaşamıştır. Salgın şu an hala devam ediyorken bile, rehberler oldukça dikkat etmesine rağmen düşüncesiz hareketlerde bulunan ve maske/sosyal mesafe kurallarına dikkat etmeyen katılımcılar ile karşı karşıya kalabilmektedirler. Hal böyle iken bu sürecin, turist rehberlerini psikolojik olarak da etkilediği görülmüştür.

Üçüncü kategori olan gelecek planlamasında; yeni normal sonrası turistlerin, seyahat davranışlarında da önemli değişiklikler yaşanacağı düşünülmektedir; toplu taşıma kullanma niyetinde düşüş, özel araçla seyahat etme isteğindeki artış ve tatilleri daha da kısaltmaya yatkınlık gibi. Salgın hala devam ediyor olduğundan, iç turizm ile başlayan turizm hareketlerinde kitle turizminin azalma göstereceği, özel ilgi turizmine ve niş pazar uygulamalarında artış yaşanacağ tahmin edilmektedir (Aydın ve Doğan, 2020). Yapılan görüşmelerde de rehberler, korona sürecinde insanların tercihlerinin değişeceği, özellikle açık havada gerçekleşecek turizm faaliyetlerinde artış yaşanacağı kanısına varmışlardır. 
Normalleşme için virüsün bu şekilde seyretmesi halinde 2021 y1lında turizm faaliyetleri için de olumsuz etkilerinin devam edeceği düşünülmektedir. Bundan dolayı rehberlerin yaşadıkları maddi kayıplar ve psikolojik yıpranmalar ile alternatif ve sektör dışı işlere yöneldiği görülmektedir. Meslekteki güvensizlik, yaşanan/yaşanabilecek salgın ve diğer olaylardan dolayı rehberler, kendilerini güvende hissettirecek mesleklere/akademik kariyere yönelmektedir. Ülkede yaşanan siyasi çatışmaların, doğal afetlerin, terör saldırılarının veya salgınların varlığında işlerini neredeyse tamamen kaybeden turizm sektörü çalışanları tamamen risk altında bulunmaktadır. Yüksek sezonda daha çok ve yevmiye usulü çalıştıklarından dolayı düzensiz geliri bulunan turist rehberleri, bu süreçte geleceklerini de öngörememektedirler. Yaşanan sürecin etkilerinin turist rehberleri açısından ne derece yüksek olduğu bu çalışmayla bir kez daha görülmektedir.

2020 Haziran itibariyle gevşetilen sert tedbirler ve yeni normal döneme geçiş ile turlar yarı kapasitede gerçekleştirilmeye başlanmış; oteller, uyulması gereken hijyen kuralları ile tekrar faaliyete geçmiştir. Turist rehberleri için de Kültür ve Turizm Bakanlığınca uyulması gereken kurallara ilişkin bir genelge yayınlanmıştır. Bu kapsamda, TUREB' in (Turist Rehberleri Birliği) turist rehberlerine hijyen ve salgın için online eğitim vermesi; turist rehberlerinin sosyal mesafe ve maske kurallarına uyması ve turistleri de sürekli uyarması, grubu bilgilendirmesi; tur araçlarında koruyucu ekipmanların yeterince bulundurulması; hastalık belirtileri gösteren katılımcıların sağlık kuruluşlarına yönlendirilmesi; katılımcıların 14 günlük sağlık öyküsü (bulundukları yerler, kronik rahatsızlıklarının olup olmaması vb.) bilgilendirmelerinin istenmesi, hastalık tanısı veya hastalığı olanlarla teması bulunan turist rehberlerinin sağlık kuruluşlarına yönelip, 14 gün çalışmaması genelge kapsamındadır (Kültür ve Turizm Bakanlığı, 2020).

Çalışmadan elde edilmiş sonuçlara göre öneriler şu şekilde özetlenebilir;

- Ekonomisini sadece turizme dayandıran ülkeler için salgının etkisi daha fazla hissedilmektedir. Bundan dolayı teknoloji, ar-ge ve diğer alanlara yapılacak yatırımlar artırilmalidir.

- Turist rehberlerinin istihdamı için Kültür ve Turizm Bakanlığı bünyesinde daha fazla çözüm önerileri sunulmalıdır, örneğin uzun vadede güvence desteğinde bulunulmalıdır.

- Turist rehberlerinin meslekleri haricinde alternatif uzmanlıklar (misafir öğretim görevliliği, çevirmenlik, yazarlık, reklam alabilecekleri blog sayfaları vb.) geliştirmeleri yararlarınadir.

- Seyahat ve turizm endüstrisinin mevcut durumdan sağ çıkabilmesi ve pandemiden sonra canlanabilmesi için hükümetten özel teşvik paketleri gereklidir. Turist rehberlerine sağlanan kredi desteğinden tam olarak yararlanamadıklarından dolayı desteğin daha da artırılması gereklidir. 
- Kitlesellikten ziyade özel ilgi turizmine yönelecek turist sayısında artış yaşanacağı düşünülmektedir. Açık hava restoranları ve doğa ile iç içe olacak işletmelerin turistler tarafından tercih edileceği tahmin edildiğinden bu alanda yatırımlar yapılmalıdır.

$\mathrm{Bu}$ çalışma Ankara Turist Rehberleri Odası'na bağlı rehberler üzerinde gerçekleştirilmiş̧ir. Çalışmanın kısıtları ve elde edilen sonuçlar, yeni çalışmaların başlangıçlarını oluşturabilir. Örneğin gelecek çalışmalarda örneklem daha da genişletilerek veya farklı bölgelerdeki rehberlere de uygulanabilir. Diğer yandan nitel olarak kurgulanan bu çalışma nicel araştırma yöntemleri kullanılarak da araştırılabilir.

\section{Kaynakça}

AHLA (2020). COVID-19 Devastating Hotel Industry: Low To Zero Hotel Revenue Driving Unprecedented Job Loss, American Hotel \& Lodging Association. https://www.ahla.com/sites/default/files/FACT\%20SHEET_COVID19\%20Impact\%2 0on\%20Hotel\%20Industry_4.22.20.pdf (Erişim tarihi: 09.07.2020)

Alaeddinoğlu, F. ve Rol, S. (2020). Covid-19 Pandemisi ve Turizm Üzerindeki Etkileri. Van Yüzüncü Yıl Üniversitesi Sosyal Bilimler Enstitüsü Dergisi, (Salgın Hastalıklar Özel Say1s1), 233-258.

Aydın, B. ve Doğan, M. (2020). Yeni Koronavirüs (COVID-19) Pandemisinin Turistik Tüketici Davranışları ve Türkiye Turizmi Üzerindeki Etkilerinin Değerlendirilmesi. Pazarlama Teorisi ve Uygulamaları Dergisi, 6(1), 93-115.

Bahar, O. ve Çelik İlal, N. (2020). Coronavirüsün (COVID-19) Turizm Sektörü Üzerindeki Ekonomik Etkileri, The, International Journal of Social Sciences and Education Research, 6(1), 125-139.

Bakar, N. A. ve Rosbi, S. (2020). Effect of Coronavirus Disease (COVID-19) to Tourism Industry, International Journal of Advanced Engineering Research and Science, 7(4), 189-193.

Brooks, S. K., Webster, R. K., Smith, L. E., Woodland, L., Wessely, S., Greenberg, N. ve Rubin, G. J. (2020). The Psychological Impact of Quarantine and How To Reduce It: Rapid Review of the Evidence. The Lancet, 395(10227), 912-920.

Butler, B. (2020). Outrageous': Qantas Criticised for Standing Down 20,000 Workers Without Pay. The Guardian https://www.theguardian.com/business/2020/mar/19/coronavirusqantas-and-jetstar-to-suspend-international-flights-and-stand-down-20000-workers

Business Insider. (2020). UK Airline Flybe Declares Bankruptcy as Coronavirus Dooms The Already Struggling Carrier. https://www.businessinsider.com/uk-airline-flybedeclares-bankruptcy-flights-grounded-2020-3 (Erişim tarihi: 11.07.2020) 
Ertuğrul DÜZGÜN, Asena KURT

Covid-19 (Koronavirüs) Salgınının Turist Rehberleri Üzerindeki Etkileri: Ankara Turist Rehberleri Odası Örneği

Chang, C.L., McAleer, M. ve Ramos, V. (2020). A Charter for Sustainable Tourism after COVID19. Sustainability 12(9), 3671.

Demir, M., Günaydın, Y. ve Demir, Ş.Ş. (2020). Coronavirüs (Covid-19)'ün Türkiye'de Turizm Üzerindeki Öncüllerinin, Etkilerinin ve Sonuçlarının Değerlendirilmesi. International Journal of Social Sciences and Education Research, 6(1), 80-107.

European Centre for Disease Prevention and Control (ECDC). (2020). COVID-19 Situation Update Worldwide. https://www.ecdc.europa.eu/en/geographical-distribution-2019ncov-cases (Erişim tarihi: 12.06.2020)

FCO (The Foreign \& Commonwealth Office). (2020). Foreign Secretary advises all British travelers to return to the UK now. https://www.gov.uk/government/news/foreignsecretary-advises-all-british-travellers-to-return-to-the-uk-now (Erişim tarihi: 12.06.2020)

Gössling, S., Scott, D. ve Hall, C. M. (2020). Pandemics, Tourism and Global Change: A Rapid Assessment of COVID-19. Journal of Sustainable Tourism, 1-20.

Haryanto, T. (2020). Covid-19 Pandemic and International Tourism Demand. JDE (Journal of Developing Economies), 5(1), 1-5.

Hawryluck, L., Gold, W. L., Robinson, S., Pogorski, S., Galea, S. ve Styra, R. (2004). SARS Control and Psychological Effects of Quarantine, Toronto, Canada. Emerging Infectious Diseases, 10(7), 1206-1212.

Huang, C., Wang, Y., Li, X., Ren, L., Zhao, J., Hu, Y., ... ve Cheng, Z. (2020). Clinical Features of Patients İnfected With 2019 Novel Coronavirus in Wuhan, China. The Lancet, 395(10223), 497-506.

IATA. (2020). COVID-19 Impact on Asia-Pacific Aviation Worsens, International Air Transport Association. https://www.iata.org/en/pressroom/pr/2020-04-24-01/ (09.07.2020)

İbiş, S. (2020). Covid-19 Salgınının Seyahat Acentaları Üzerine Etkisi. Safran Kültür ve Turizm Araştırmaları Dergisi, 3(1), 85-98.

Jeong, H., Yim, H. W., Song, Y.-J., Ki, M., Min, J.-A., Cho, J. ve Chae, J.-H. (2016). Mental Health Status of People Isolated due to Middle East Respiratory Syndrome. Epidemiology and Health, 38.

Karasar, N. (1995). Bilimsel Araştırma Yöntemi. Ankara: 3A Araştırma Eğitim Danışmanlık.

Karim, W., Haque, A., Anis, Z. ve Ulfy, M. A. (2020). The Movement Control Order (MCO) for COVID-19 Crisis and Its Impact on Tourism and Hospitality Sector in Malaysia. International Tourism and Hospitality Journal, 3(2), 1-7. 
Khadka, D., Pokhrel, G. P., Thakur, M. S., Magar, P. R., Bhatta, S., Dhamala, M. K. ve Bhuju, D.R. (2020). Impact of COVID-19 on the Tourism Industry in Nepal. Asian Journal of Arts, Humanities and Social Studies, 3(1), 40-48.

Khan, M., Chelliah, S. ve Ahmed, S. (2017). Factors Influencing Destination Image and Visit Intention Among Young Women Travellers: Role of Travel Motivation, Perceived Risks, And Travel Constraints, Asia Pacific Journal of Tourism Research, 22(11), 11391155 .

Kıvılcım, B. (2020). COVID-19 (Yeni Koronavirüs) Salgınının Turizm Sektörüne Muhtemel Etkileri. USOBED Uluslararası Batı Karadeniz Sosyal ve Beşerî Bilimler Dergisi, 4(1), $17-27$.

Kiper, V. O., Saraç, Ö., Çolak, O. ve Batman, O. (2020). Covıd-19 Salgınıyla Oluşan Krizlerin Turizm Faaliyetleri Üzerindeki Etkilerinin Turizm Akademisyenleri Tarafindan Değerlendirilmesi. Balıkesir Üniversitesi Sosyal Bilimler Enstitüsü Dergisi, 23(43), $527-551$.

Kock, F., Josiassen, A. ve Assaf, A. G. (2019b). The Xenophobic Tourist. Annals of Tourism Research, 74, 155-166.

Kültür ve Turizm Bakanlığı (2020). Turist Rehberliği Hizmetinde COVID-19 Pandemi Sürecinde Uyulması Gereken Kurallara İlişkin Genelge (95420461-010.06.02-E.385761) (Erişim tarihi: 17.07 .2020$)$

Lee, C.-C., ve Chen, C.-J. (2011). The Reaction of Elderly Asian Tourists to Avian Influenza and SARS. Tourism Management, 32(6), 1421-1422.

Liu, X., Kakade, M., Fuller, C. J., Fan, B., Fang, Y., Kong, J., Guan, Z. ve Wu, P. (2012). Depression after Exposure to Stressful Events: Lessons Learned from The Severe Acute Respiratory Syndrome Epidemic. Comprehensive Psychiatry, 53(1), 15-23.

Loureiro, S. ve Jesus, S. (2019). How Perceived Risk And Animosity Towards A Destination May Influence Destination Image and Intention To Revisit: The Case of Rio De Janeiro, Anatolia, 30(4), 497-512.

Lyall, L. M., Wyse, C. A., Graham, N., Ferguson, A., Lyall, D. M., Cullen, B., Celis Morales, C. A., Biello, S. M., Mackay, D., Ward, J., Strawbridge, R. J., Gill, J. M. R., Bailey, M. E. S., Pell, J. P. ve Smith, D. J. (2018). Association of Disrupted Circadian Rhythmicity With Mood Disorders, Subjective Wellbeing, and Cognitive Function: A CrossSectional Study Of 91105 Participants from the UK Biobank. The Lancet Psychiatry, $5(6), 507-514$.

Makwana, N. (2019). Disaster and İts İmpact On Mental Health: A Narrative Review. Journal of Family Medicine and Primary Care, 8(10), 3090. 
Ertuğrul DÜZGÜN, Asena KURT

Covid-19 (Koronavirüs) Salgınının Turist Rehberleri Üzerindeki Etkileri: Ankara Turist Rehberleri Odası Örneği

McKercher, B., ve Chon, K. (2004). The Over-Reaction to SARS and The Collapse of Asian Tourism. Annals of Tourism Research, 31(3), 716-719.

Mert, G. ve Alan, T. (2020). Girişimcilerin Kriz Algısı ve Kriz ile Başa Çıkma Stratejileri, International Social Mentality and Researcher Thinkers Journal, (Issn:2630-631X) 6(32): 1047-1064.

Nazneen, S., Hong, X. ve Ud Din, N. (2020). COVID-19 Crises and Tourist Travel Risk Perceptions. SSRN. Erişim: http://dx.doi.org/10.2139/ssrn.3592321

Patton, M. Q. (2002). Qualitative Research and Evaluation Methods (3rd ed.). Thousand Oaks, CA: Sage Publications.

Patton, M. Q. (2005). Qualitative Research. New York: John Wiley \& Sons, Ltd.

Ranasinghe, R., Damunupola, A., Wijesundara, S., Karunarathna, C., Nawarathna, D., Gamage, S., Ranaweera, A. ve Idroos, A. A. (2020). Tourism After Corona: Impacts of Covid 19 Pandemic and Way Forward for Tourism, Hotel And Mice Industry in Sri Lanka, 1-19.

Rico-Uribe, L. A., Caballero, F. F., Martín-María, N., Cabello, M., Ayuso-Mateos, J. L. ve Miret, M. (2018). Association of Loneliness With All-Cause Mortality: A Meta-Analysis. PloS one, 13(1), $\mathrm{e} 0190033$.

Rona, R. J., Fear, N. T., Hull, L., Greenberg, N., Earnshaw, M., Hotopf, M. ve Wessely, S. (2007). Mental Health Consequences of Overstretch in The UK Armed Forces: First Phase of A Cohort Study. BMJ, 335(7620), 603.

Russy, D. ve Smith, R. (2013) The Economic Impact of H1N1 on Mexico's Tourist and Pork Sectors. Health Economics, 22(7).

Sezen Doğancılı, O. (2020). COVID-19 Salgını Sonrası Turizm Destekleri, Türk Turizm Araştırmaları Dergisi, 4(3): 2808-2820.

Sheresheva, M. Y. (2020). Coronavirus and Tourism, Population and Economics, 4(2), 72-76.

Siu, A. ve Wong, Y. R. (2004). Economic Impact of SARS: The Case of Hong Kong. Asian Economic Papers, 3(1), 62-83.

Sood, S. (2020). Psychological Effects of the Coronavirus Disease-2019 Pandemic. Research \& Humanities in Medical Education, 7, 23-26.

STR (2020). COVID-19- A Global İnsight on Travel and Tourism İmpacts UNWTO \& Data

Partners, Smith Travel Research. https://webunwto.s3.eu-west-1.amazonaws.com/s3fspublic/2020-03/21_4_Tourism_COVID19_Data_Coalitionpptx.pdf (Erişim tarihi: 09.07.2020)

UNWTO. (2020a). COVID-19: UNWTO Calls on Tourism to Be Part Of Recovery Plans. https://www.unwto.org/news/covid-19-unwto-calls-on-tourism-to-be-part-of-recoveryplans (Erişim tarihi: 12.06.2020) 
UNWTO. (2020b). International Tourist Arrivals Could Fall by 20-30\% in 2020. https:// www.unwto.org/news/international-tourism-arrivals-could-fall-in-2020 (Erişim tarihi: 12.06.2020)

Viboud, C. ve Simonsen, L. (2012). Global Mortality of 2009 Pandemic Influenza A H1N1. The Lancet Infectious Diseases, 12(9), 651-653.

Wang, I. M. ve Ackerman, J. M. (2019). The Infectiousness of Crowds: Crowding Experiences Are Amplified By Pathogen Threats. Personality and Social Psychology Bulletin, 45(1), 120-132.

Washington Post. (2020). US Intelligence Reports From January and February Warned About A Likely Pandemic. https://www.washingtonpost.com/national-security/us-intelligencereports-from-januaryand-february-warned-about-a-likely-

pandemic/2020/03/20/299d8cda-6ad5-11ea-b5f1-a5a804158597_story.html (Erişim tarihi: 14.06 .2020 )

Wen, J., Kozak, M., Yang, S. ve Liu, F. (2020). COVID-19: Potential Effects on Chinese Citizens' Lifestyle and Travel. Tourism Review.

World Bank. (2020a). Air Transport, Passengers Carried. https://data.worldbank.org/indicator/is.air.psgr (Erişim tarihi: 12.06.2020)

World Bank. (2020b). International Tourism, Number of Arrivals. https://data.worldbank.org/indicator/ST.INT.ARVL (Erişim tarihi: 12.06.2020)

Şimşek, H. ve Yıldırım, A. (2011). Sosyal Bilimlerde Nitel Araştırma Yöntemleri. Ankara: Seçkin Yayıncılık.

Yenişehirlioğlu E. ve Salha H. (2020). Covid 19 Pandemisinin Türkiye İç Turizmine Yansımaları: Değişen Talep Üzerine Bir Araştırma, İstanbul Ticaret Üniversitesi Sosyal Bilimler Dergisi COVID-19 Sosyal Bilimler Özel Sayısı, 19 (37), 355-368.

Zengin, Y., Topçuoğlu, E. ve Kaygın, E. (2020). Covid-19 Salgınının Aşçıların Çalışma Hayatına Etkisi: Kars İli Örneği. Çalışma İlişkileri Dergisi, 11(1), 1-17.

Zhang, W., Gu, H. ve Raphael, R. (2005). The Impacts of SARS on The Consumer Behaviour of Chinese Domestic Tourists. Current Issues in Tourism, 8(1), 22-38. 